\title{
Pelatihan Pembuatan dan Pengemasan Teh Serai Murni sebagai Langkah Diversifikasi Produk Pertanian Dusun Precet
}

\author{
Achmad Naschicuddin ${ }^{1}$, Heni Widayani ${ }^{2}$, Ria Dhea N.K ${ }^{3}$ \\ ${ }^{1}$ Fakultas Kedokteran dan Ilmu Kesehatan, UIN Maulana Malik Ibrahim Malang \\ ${ }^{2,3}$ Program Studi Matematika, UIN Maulana Malik Ibrahim Malang) \\ nashichuddin@gmail.com, heniwidayani@mat.uin-malang.ac.id, riadhea@mat.uin-malang.ac.id
}

\section{Info Artikel}

\section{Riwayat Artikel:}

Diterima: Agustus 2021

Direvisi: Agustus 2021

Diterbitkan: September 2021

\section{Keywords:}

Lemongrass

Tea

Community Services

Dusun Precet

\begin{abstract}
Community service program is one of activity to implement theories and concepts which develop in university to solve real problems in community. One of the service activities that can be done is optimizing the value of local products so that they can have more selling value by utilizing appropriate technology. Dusun Precet has a local lemongrass which is planted in every yard of the house. This agricultural products has not been used optimally. One way to increase the selling value of this lemongrass plant is not only to use as cooking spices, but also to be processed into pure lemongrass tea which has a distinctive fragrance with a strong taste. This program received a positive response from Dusun Precet residents especially the PKK Group took the initiative to try processing and packaging their own lemongrass tea after the completion of the training event.
\end{abstract}

\section{Korespondensi:}

Heni Widayani,

UIN Maulana Malik Ibrahim Malang,

Jl. Gajayana No. 50 Malang, Jawa Timur, Indonesia 65144

heniwidayani@mat.uin-malang.ac.id

\section{PENDAHULUAN}

Serai (Cymbopogon) atau Lemongrass merupakan tumbuhan anggota dari suku rumput-rumputan dan sering dijumpai di daerah tropis seperti di Indonesia. Serai dapat dimanfaatkan dalam berbagai hal seperti memasak, obat herbal, kesehatan, kosmetik dan sebagainya. Selain itu, serai mudah ditanam dan tidak memerlukan perawatan yang sulit. Proses menanam serai hanya membutuhkan media air dan tanah saja.

Sumbersekar merupakan salah satu desa dari sepuluh desa yang berada di Kecamatan Dau Kabupaten Malang. Desa Sumbersekar memiliki empat dusun salah satunya Precet. Mata pencaharian warga dusun tersebut yaitu pertanian, peternakan, perikanan dan perkebunan. Di daerah ini tumbuhan serai sangat melimpah, namun kurang dimanfaatkan oleh warga. Sehingga serai dapat dimanfaatkan secara maksimal di wilayah ini dengan cara melakukan edukasi pemanfaatan serai. Disamping itu serai dikenal sebagai tumbuhan obat dan diharapkan nantinya dapat memiliki nilai jual dan mendongkrak perekonomian masyarakat di Precet. Didukung dengan adanya kontur tanah di daerah Precet yang cocok untuk menanam serai.

Hasil panen serai dari petani masih dipasarkan secara tradisional atau bahkan hanya dijadikan bumbu masak untuk warga yang memiliki tumbuhan serai di halamannya. Namun, karena kondisi pandemi serai yang dipanen akan cepat membusuk sedangkan saat memasak tidak selalu menggunakan serai. Padahal manfaat serai berbagai macam bahkan untuk obat serangga alami atau minuman herbal untuk menghilangkan kecemasan atau masalah pencernaan. Minuman herbal serai dapat dibuat dengan cara digeprak kemudian direbus dengan air atau dapat ditambahkan madu. Namun akan sangat mudah dibuat jika tinggal diseduh saja. Misalnya dengan cara dibuat 
bubuk serai. Sehingga ketika ingin membuat minuman herbal atau memasak dapat dituangkan sesuai dengan kebutuhan.

\section{METODE PENELITIAN}

Lokasi yang dijadikan tempat pengabdian adalah Desa Sumbersekar Kecamatan Dau Kabupaten Malang, meupakan salah satu desa yang berada di Kecamatan Dau dan memiliki 4 dusun salah satunya Precet. Desa Sumbersekar terdapat tumbuhan serai yang tumbuh subur di sepanjang jalan maupun di pemukiman warga. Suburnya tumbuhan ini membuat warga terkadang kewalahan untuk memanfaatkan melimpahnya serai. Mata pencaharian warga Dusun Precet salah satunya pedagang. Mereka membawa hasil panen serai dari halaman mereka. Namun, mereka belum dapat memanfaatkan serai selain bumbu dapur. Berikut peta topologi Dusun Precet yang berada di Kabupaten Malang dan menjadi tempat pengabdian.

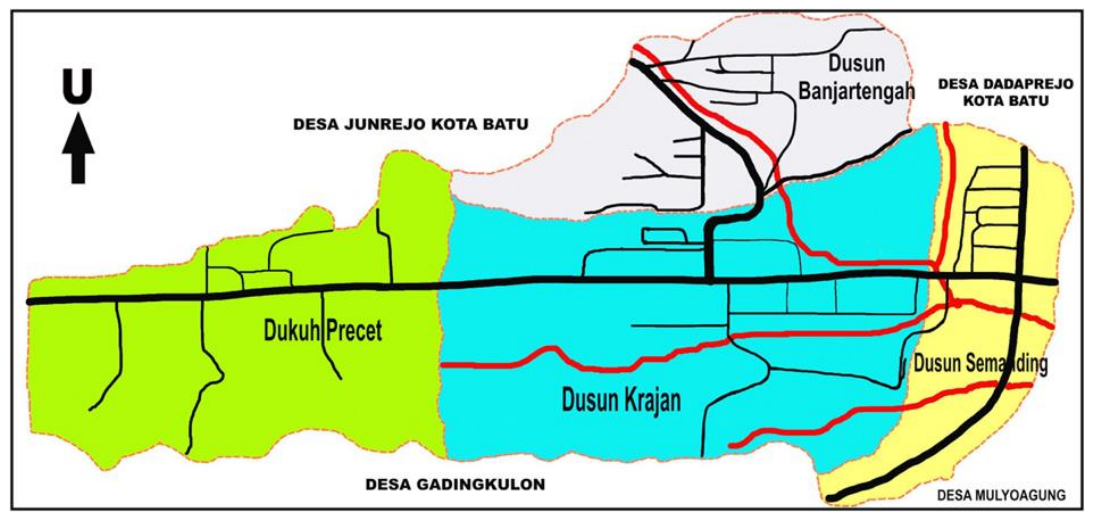

Gambar 3. Lokasi Pengabdian Dusun Precet

Serai atau Cymbopogen citratus merupakan tumbuhan yang masuk dalam keluarga rumput-rumputan atau Gramineae dan populer di Indonesia. Bahkan di negara Brazil, serai digunakan untuk keperluan medis herbal atau folk medicine (Carlini E.A, dkk, 1986). Menurut Skaria B.P, dkk (2006) serai dapat digunakan untuk kosmetik dan obat herbal. Selain itu, digunakan untuk terapi mental dan menghilangkan ketombe (Khan, N.T, 2020). Kandungan dalam serai yaitu A, B, dan C (Nambiar, V.S dan Matela, H, 2012), dapat juga menguatkan sistem kekebalan tubuh (Prasad A., dkk,1998), memperbaiki sel-sel yang rusak karena mengandung magnesium serta fosfor untuk pertumbuhan DNA/RNA serta sintesis sel membran (Singh M., dkk, 2012).

Melimpahnya tumbuhan serai yang memiliki banyak manfaat namun akan kurang bermanfaat jika tidak dapat diolah dengan baik. Salah satunya pemanfaatan serai dengan cara menjadikan serai menjadi bubuk sehingga dimanfaatkan sebagai minuman herbal ataupun sebagai bumbu masakan. Selain itu membuat serai tidak mudah busuk karena telah diolah dan diproses secara alami. Berikut langkah-langkah dalam pembuatan bubuk serai

1. Serai dipanen kemudian diambil bagian pangkal dekat akar

2. Serai yang dipanen dikupas kulit luarnya

3. Serai yang sudah dikupas kemudian dicuci bersih

4. Potong serai yang sudah dicuci sepanjang $30 \mathrm{~mm}$

5. Keringkan potongan serai tersebut dengan cara dijemur di bawah sinar matahari selama 48 jam. Menurut penelitian yang dilakukan (Shahdri, S., dkk, 2018) serai yang paling baik dikeringkan dalam waktu 48 jam dengan suhu $60^{\circ} \mathrm{C}$ yang mana telah dilakukan uji organoleptik

6. Setelah itu haluskan dengan alat penghalus sehingga menjadi bubuk atau granula. Granula ini akan mengeluarkan aroma khas dari serai kembali, dan siap untuk dikemas ke dalam kantong teh

7. Teh sereh dikemas dalam kemasan yang sudah disediakan 


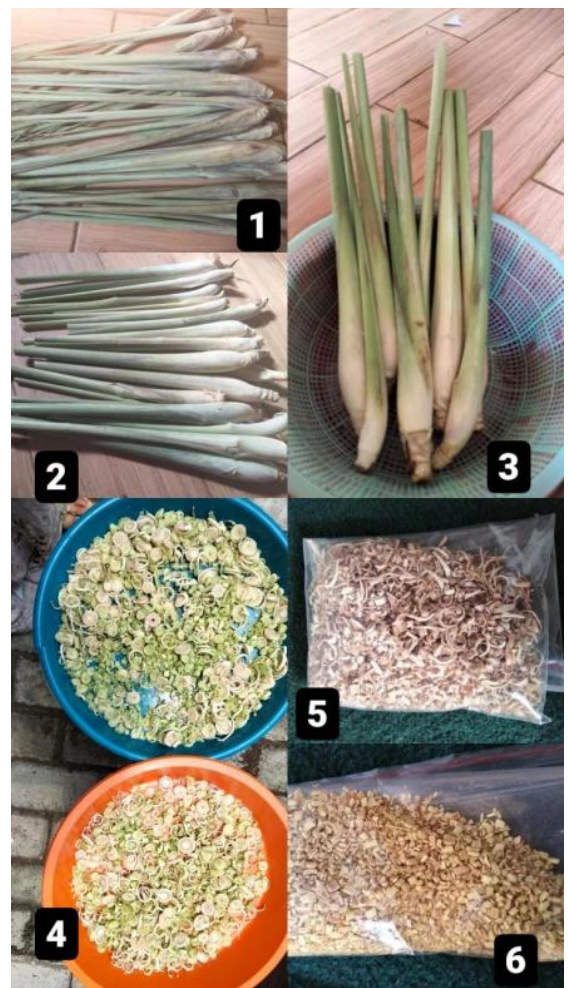

(a) Langkah pengolahan serai

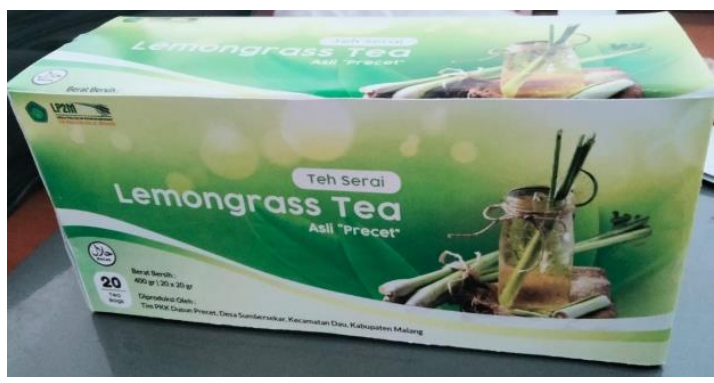

(b) Kemasan Produk Teh Serai

Gambar 4. Langkah pengolahan dan pengemasan Teh Serai

Bubuk serai yang telah diolah dapat dijual kembali. Sebelum dijual sebaiknya dikemas terlebih dahulu supaya lebih menarik sehingga dapat memiliki nilai jual yang tinggi. Pemasaran produk serah kemasan ini dapat dijual di KUD di Kabupaten Dau atau lewat market place atau dapat dijual di pasar.

Analisis yang digunakan dalam pengabdian ini yaitu analisis SWOT. Analisis ini akan dilakukan pada kelompok petani serah, kelompok PKK, serta KUD di Kabupaten Dau pada prospek produk pertanian dari Dusun Precet. Peran KUD Dau menjadi sangat penting sebagai fasilitator dan penggerak perekonomian petani Qaryah Thayyibah sehingga dapat bersinergi untuk mengatasi hasil serai yang melimpah. Kelompok tani serta kelompok PKK diharapkan dapat berpartisipasi aktif dalam program penyuluhan dan pendampingan, sehingga dapat menduplikasi program menjadi UKM di bawah KUD yang mengembangkan pemasaran hasil panen serai secara lebih luas.

\section{HASIL DAN PEMBAHASAN}

Serai merupakan tumbuhan abadi yang hidup di daerah tropis (Skaria, B.P, dkk, 2006). Kandungan dan manfaat tumbuhan serai bermacam-macam. Selain digunakan sebagai bumbu masak dan pengusir nyamuk, serai memiliki kandungan yang baik untuk kesehatan. Serai memiliki aktivitas antibakteri yang dapat menghambat pertumbuhan bakteri E.coli dan Staphylococcus aereus (Poelangan, 2009) serta memiliki kandungan zat anti inflasi yang digunakan untuk mengurangi peradangan mukosa mulut (Shadri, S., dkk, 2018). Serai dapat diolah berupa bubuk serai untuk mempermudah distribusi di pasar, selain itu untuk mengurangi resiko membusuk jika dibiarkan terlalu lama. Pengolahan serai dapat dilakukan dengan menggunakan tenaga matahari kemudian dihaluskan dengan menggunakan mesin penghalus. Hasil dari bubuk serai tersebut dapat langsung dimanfaatkan misalnya untuk minuman herbal atau dicampur langsung untuk masakan.

Hasil atau output yang diharapkan pada pengabdian ini diharapkan masyarakat di Dusun Precet mampu mengolah hasil panen maupun yang tumbuh liar tumbuhan serai di sekitar serta memiliki jual tinggi. Langkahlangkah pemecahan masalah dapat dilihat pada Gambar 4 berikut ini.

Community Development memberikan penekanan pada prinsip kemandirian. Artinya partisipasi aktif dalam bentuk aksi bersama - group action - di dalam memecahkan masalah dan memenuhi kebutuhankebutuhannya dilakukan berdasarkan potensi-potensi yang dimiliki masyarakat. Community Development dengan segala kegiatannya dalam pembangunan menghindari metode kerja "doing for the community", tetapi mengadopsi metode kerja "doing with the community". Metode kerja doing for, akan menjadikan masyarakat menjadi pasif, kurang kreatif dan tidak berdaya, bahkan mendidik masyarakat untuk bergantung pada bantuan pemerintah atau 
organisasi-organisasi sukarela pemberi bantuan. Sebaliknya, metode kerja doing with, merangsang masyarakat menjadi aktif dan dinamis serta mampu mengidentifikasi mana kebutuhan yang sifatnya - real needs, felt needs dan expected need. Metode kerja doing with, sangat sesuai dengan gagasan besar Ki Hajar Dewantara tentang kepemimpinan pendidikan di Indonesia - ing ngarso sung tulodo, ing madyo mangun karso, dan tut wuri handayani - yang berfokus akan perlunya kemandirian yang partisipatif di dalam proses pembangunan (Rahardi, D., 2019).

Kegiatan dilakukan pada tanggal 30 September 2021 pukul 16.00-17.00 WIB di Balai RW Dusun Precet. Peserta workshop adalah perwakilan kader PKK Dusun Precet sejumlah 20 orang. Pembatasan jumlah peserta dan pembagian masker oleh tim pengabdian dilakukan sebagai langkah penerapan physical distancing agar kegiatan pengabdian tidak menjadi kluster baru penyebaran COVID 19. Selain itu, para peserta yang hadir diwajibkan untuk terlebih dahulu menggunakan hand sanitizer yang sudah disediakan oleh panitia di meja absensi.

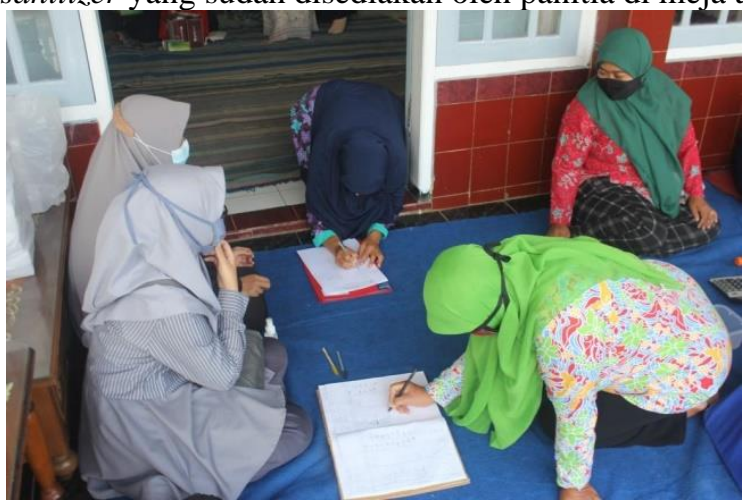

Gambar 5. Absensi Obyek Dampingan

Setelah dilakukan absensi selanjutnya diawali dengan pembukaan oleh ketua pengapdian kemudian dilanjutkan sambutan Kepala Dusun Precet. Masyarakat sebagai obyek dampingan diberi edukasi mengenai manfaat serai sebagai minuman herbal. Kemudian memproduksi secara mandiri dan memiliki nilai jual yang tinggi. Obyek dampingan juga telah disediakan alat untuk mengolah serai yang melimpah menjadi serbuk minuman herbal. Ide ini disambut oleh obyek dampingan karena melimpahnya hasil panen seri di rumah warga setempat.

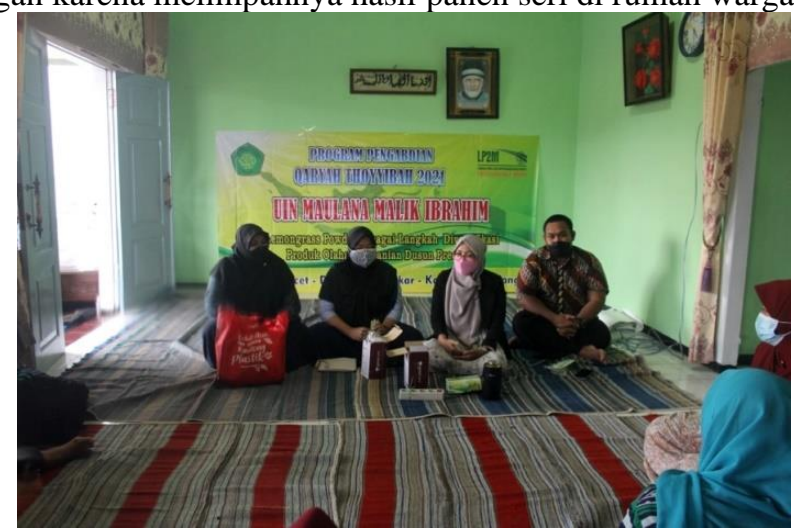

Gambar 6. Tim Memberikan Pengarahan Terkait Penelitian

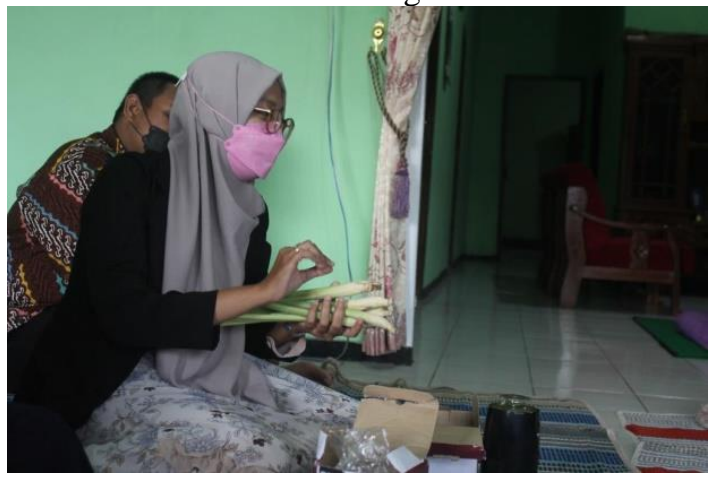

Gambar 7. Tim sedang Menjelaskan manfaat Serai 


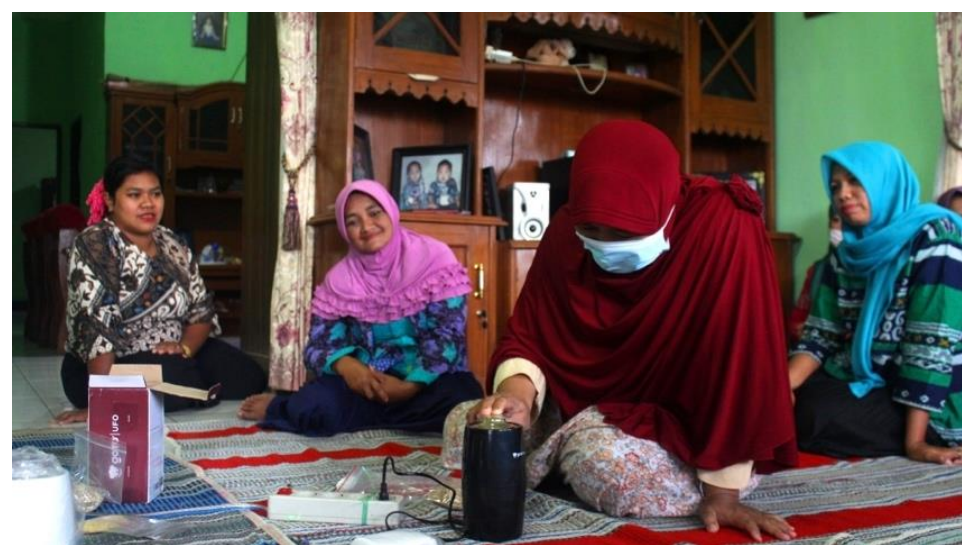

Gambar 9. Peserta Mencoba Alat yang Digunakan

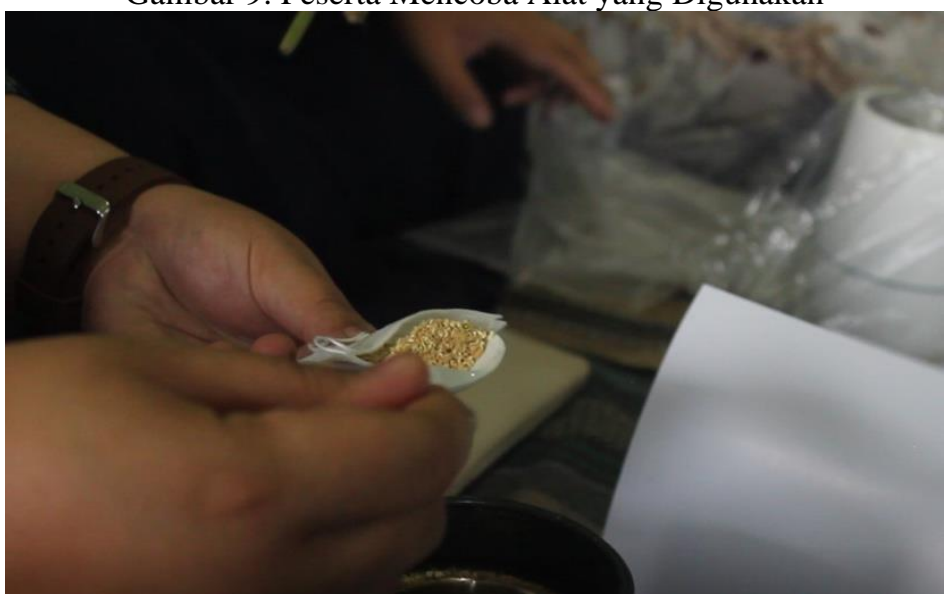

Gambar 10. Teh Serai Herbal yang Dikemas

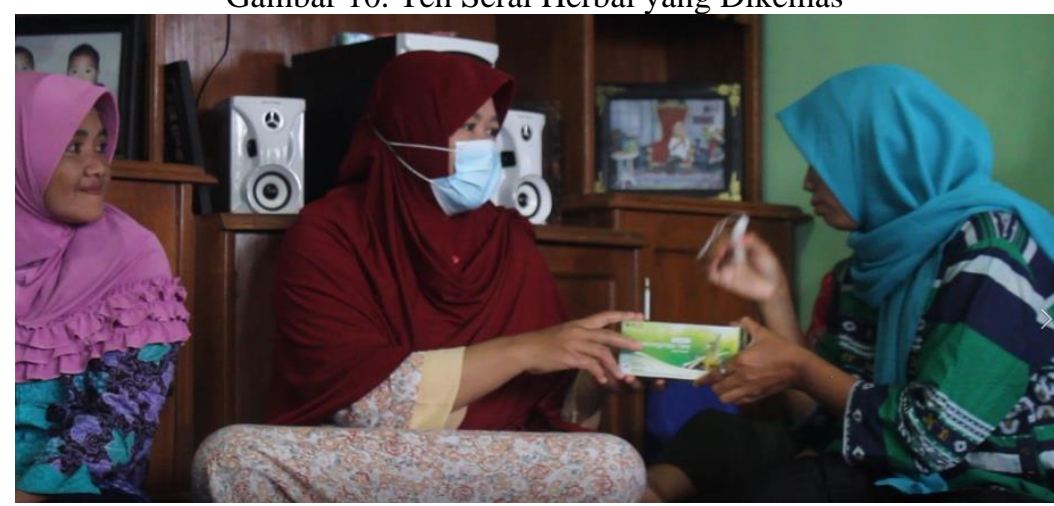

Gambar 11. Packaging Teh Serai

Pengabdian yang dilakukan dengan obyek dampingan masyrakat Dukun Precet menyambut antusias Pengabdian Masyarakat ini. Mereka akan melakukan pameran UMKM mendatang dengan membawa produk andalan mereka terbaru yaitu teh serai ini dan sayuran potong dimana hasil Qaryah Thayibbah tahun 2020. Diharapkan kegiatan ini dapat membantu mendongkrak perekonomian masyrakat sekitar.

\section{KESIMPULAN}

Pelatihan pengolahan teh serai murni di Dusun Precet, Desa Sumbersekar, Kabupaten Malang mendapatkan respons positif dari warga dusun, terutama ibu-ibu PKK Dusun Precet. Sejauh ini, Dusun Precet memiliki beberapa produk khas lokal yang sudah dipasarkan seperti jahe bubuk dan kopi bubuk. Ide produk khas baru yakni Teh Serai murni menjadi produk inovatif yang bisa menambah harga jual dari tanaman serai yang dibudidayakan warga. Tanaman ini tumbuh di setiap rumah warga namun belum dimanfaatkan dengan optimal. Warga sejauh ini baru menggunakan serai untuk konsumsi rumah tangga, yakni sebagai bumbu masak saja. Khasiat serai yang lain belum terekspos karena ketidaktahuan warga untuk mengolah tanaman ini. Pengolahan tanaman serai menjadi teh diharapkan dapat menjadi produk yang diterima pasar dengan lama ketahanan yang cukup lama, sehingga dapat menjadi salah satu sumber pendapatan warga dari berbudidaya tanaman serai. Selain itu, teknik pengolahan teh serai 
juga dapat diduplikasi pada hasil pertanian yang lain. Apabila tidak dikemas dalam bentuk teh, serai juga bisa dijadikan dalam bentuk bubuk dengan alat grinder yang dimiliki. Pemanfaatan serai sebagai bumbu makanan pun akan bisa lebih meluas, tidak hanya terbatas pada konsumsi pribadi per rumah tangga.

\section{UCAPAN TERIMAKASIH}

Terima kasih kepada Lembaga Penelitian dan Pengabdian Masyarakat (LP2M) Universitas Islam Negeri Maulana Malik Ibrahim Malang, Kelompok PKK Dusun Precet, Desa Sumbersekar, Kabupaten Malang, Ibu Khusnul serta Kepala Dusun Precet yang telah mendukung serangkaian kegiatan pengabdian masyarakat ini

\section{DAFTAR PUSTAKA}

[1] Carlini, E.A, Contar, Juida De D.P, Silva-Fiho, A.R, Silveira-Filho, N.G.DA, Frochtengarten, M.L, Bueno, O.F.A. 1986. Lemongrass (Cymbopogon Cztratus Stapf): Effects of Teas Prepared from Pharmacology of The Leaves on Laboratory Animals. Journal of Ethnopharmacology, 37-64 Elsevier Scientific Publishers Ireland Ltd

[2] Skaria, B.P, Joy P.P, Mathew, G., Mathew, S., Joseph A., Aromatic and Medicinal Plants Research Station, India. 2006. Handbook of Herbs and Spices Volume 3. ISBN 978-1-84569-017-5. Woodhead Publishing Limited

[3] Khan, N.T., 2020. Therapeutic Benefits of Lemongrass and Tea Tree. Annals of Civil and Environmental Engineering. https://doi.org/10.29328/journal.acee.1001022. ISSN 2574-0350

[4] Nambiar VS, Matela H. Potential functions of lemon grass (Cymbopogon citratus) in health and disease. Int J Pharmaceut Biol Arc. 2012; 3: 1035-1043

[5] Prasad A, Kumar D, Singh DV. Effect of soil sodicity on the growth and cationcomposition of palmarosa and lemongrass. Journal of herbs, spices \& medicinal plants. 1998; 5: 51-60.

[6] Singh M, Nagar N, Upadhyay Ak, Chandel BS. Effect of potassium and zinc onyield, mineral composition and quality of lemon grass under saline condition. Annals of Plantand Soil Research. 2012; 14: 101-104.

[7] Poelongan, M. 2009. The Effects of Lemongrass (Andropogon citratus DC.) Extract to the Growth of Bacteria Isolated from Subclinical Mastitis RiddenCows. Universitas Kristen Martadinata. Bogor.

[8] Shadri, S., Moulana, R.M., Safriani, N., 2018. Kajian Pembuatan Bubuk Serai Dapur (Cymbopogon citratus) dengan Kombinasi Suhu dan Lama Pengeringan. Jurnal Ilmiah Mahasiswa Pertanian Unsyiah Volume 1, Nomor 3, Febuari 2018 www.jim.unsyiah.ac.id/JFP 